\title{
Potential of fungi isolated from a mangrove ecosystem in Northern Sulawesi, Indonesia: Protease, cellulase and anti-microbial capabilities
}

\author{
AGUS TRIANTO ${ }^{1,2, \boldsymbol{v}}$, OCKY KARNA RADJASA ${ }^{1,3}$, SUBAGIYO $^{1}$, HARTUTI PURNAWENI ${ }^{4}$, \\ MUHAMMAD SYAIFUDIEN BAHRY ${ }^{3}$, RIGNOLDA DJAMALUDIN ${ }^{5}$, AIYEN TJOA ${ }^{6}$, IAN SINGLETON ${ }^{7}$, \\ KAREN DIELE ${ }^{7}$, DARREN EVAN ${ }^{8}$ \\ ${ }^{1}$ Department Marine Science, Faculty of Fisheries and Marine Science, Universitas Diponegoro. J1. Prof. Soedarto, SH, Tembalang, Semarang 50275, \\ Central Java, Indonesia. Tel. +62-24-7474698, `email: agustrianto.undip@gmail.com \\ ${ }^{2}$ Natural Product Laboratory, Centre for Research and Services, Universitas Diponegoro. Jl. Prof. Soedarto, SH, Tembalang, Semarang 50275, Central \\ Java, Indonesia \\ ${ }^{3}$ Tropical Marine Biodiversity Laboratory, Faculty of Fisheries and Marine Science, Universitas Diponegoro. Jl. Prof. Soedarto, SH, Tembalang, \\ Semarang 50275, Central Java, Indonesia \\ ${ }^{4}$ Department Public Administration, Faculty of Social and Politic Science, Universitas Diponegoro. J1. Prof. Soedarto, SH, Tembalang, Semarang 50275, \\ Central Java, Indonesia \\ ${ }^{5}$ Department of Marine Science, Faculty of Fisheries and Marine Science, Universitas Sam Ratulangi. J1. Kampus Unsrat, Kleak-Bahu, Manado 95115, \\ North Sulawesi, Indonesia \\ ${ }^{6}$ Faculty of Agriculture, Universitas Tadulako. J1. Soekarno Hatta Km. 9, Tondo, Mantikulore, Palu 94148, Central Sulawesi, Indonesia \\ ${ }^{7}$ School of Applied Sciences, Edinburgh Napier University. Sighthill Campus, 9 Sighthill Court, Edinburgh, EH11 4BN, UK \\ ${ }^{8}$ School of Natural and Environmental Sciences, New Castle University, Agriculture Building, King's Road, Newcastle upon Tyne NE1 7RU, UK
}

Manuscript received: 17 January 2021. Revision accepted: 9 March 2021.

\begin{abstract}
Trianto A, Radjasa OK, Subagiyo, Purnaweni H, Bahry MS, Djamaludin R, Tjoa A, Singleton I, Diele K, Evan D. 2021. Potential of fungi isolated from a mangrove ecosystem in Northern Sulawesi, Indonesia: Protease, cellulase and anti-microbial capabilities. Biodiversitas 22: 1717- 1724. The high and relatively unexplored diversity of fungi present in the mangrove ecosystem represents a source of novel biotechnological importance. This study explored the potential of fungi isolated from the mangrove ecosystems to produce proteases and cellulases (commercially important enzymes) and their ability to inhibit pathogenic Vibrio species. Random samples of root, branch, leaf, sediments and litters were collected from 5 different mangrove sites in Manado, North Sulawesi, as a source of fungal isolates. The fungi were isolated on malt extract agar (MEA) and potato dextrose agar (PDA). The isolates were identified mainly based on the molecular methods (18S gene sequence) and examined for their ability to produce proteases, cellulases, and activity against several Vibrio species. Altogether 288 species of fungi were isolated from all samples. The fungi, isolated from leaves showed the highest diversity. A fungal isolate 19 Mba-C2-1 Fusarium equiseti from Avicennia sp. leaf showed the highest protease activity. While, the isolate 19 MT-05-3 Hypocrea sp. from sediment had the highest cellulase activity. From the root of Rhizophora sp., the isolate 19 MT-04-3 identified as Trichoderma viride had the strongest activity against a range of Vibrio species. This work indicates the high potential of fungi isolated from mangrove ecosystems as a source of commercially important enzymes and novel antimicrobial compounds.
\end{abstract}

Keywords: Aquaculture diseases, bioprospecting, Eurotiomycetes, fungal enzyme, internal transcribed spacer, Sordariomycetes

\section{INTRODUCTION}

Mangrove is an essential component of our ecosystems and has huge but relatively unexplored biodiversityparticularly fungal biodiversity. These fungi could have huge biotechnology potential for production of enzyme and antibacterial compounds. Cellulase and protease enzyme has promising biological prospects for discovering potential biocatalysts for use in hydrolysis of lignocellulosic materials and proteic residues. These enzymes can increase and ensure viable production of second-generation ethanol from different and alternative sources (Immaculatejeyasanta et al. 2011; Ramesh et al. 2014). Vibrio is a pathogenic-bacteria found in the environment and community with a high-risk infection (Igbinosa and Omoruyi 2016).

Manado is the largest coastal population in North Sulawesi, Indonesia, having $4.6 \%$ of $161 \mathrm{~km}^{2}$ area under forest and mangrove. It is an interesting area to harboring the richness of microorganisms. Mangrove forests are uniquely valuable coastal wetlands in the transition zone between land and sea, which moderates freshwater flows from inland while coping with tidal inundation. They sustain millions of people globally, contributing to their survival and welfare through protection against coastal erosion, provision of food and material for construction and firewood, and through filtering of water-borne pollutants, which improves the water quality (Brown and Djamaluddin 2017; Djamaluddin 2018; Hadika and Karuniasa 2020). Mangrove forests are also globally important carbon sinks with carbon densities exceeding 8 times those typical for terrestrial tropical forests (Hossain 2016). They are considered as high priority habitats in climate change mitigation and adaptation strategies (Nehren et al. 2017; Indarsih and Masruri 2019). Mangrove fungi are known to be rich sources of enzymes and secondary metabolites with 
various applications such as proteinase, cellulose, and antibacterial compounds (Sari et al. 2017; Maitig et al. 2018; Sibero et al. 2018). Many studies have shown the importance of using mangrove-derived fungi. The enzymes derived from mangrove-associated microorganisms have economic value for industrial and medical purposes. Previous study has shown that Aspergillus niger, Halocyphina villosa, and Lignicola longirostris are known to produce protease and cellulase (Immaculatejeyasanta et al. 2011).

Protease is an enzyme that performs proteolysis (protein catabolism by hydrolysis of peptide bonds). Proteases are used in industry, medicine, and daily life, e.g., in drug production, controlling blood clotting, as a substituent of detergents (Kamath et al. 2010). Proteases have been applied in environmental bioremediation of proteinpolluted areas (through excess feeds) near fish or shrimp ponds to improve water quality (de Souza et al. 2015). Thus, proteases can also act as biocontrol of pathogens, such as Vibrio. Cellulase is an enzyme that can break the cellulose bonds into oligo, di, or mono-saccharides. It breaks cellulose through hydrolysis into simple saccharides called cellodextrin (Kelecom 2002). Unlike other compounds, cellulose is an abundant natural biopolymer on earth. Microorganisms, such as fungi, produce cellulase to degrade cellulose by hydrolyzing the glycoside linkages of cellulose. Previous studies have reported that six fungi such as Acremonium sp. Alternaria chlamydospora, Alternaria sp., Aspergillus sp., Fusarium sp., and Pestalotiopsis sp., isolated from mangrove root of Avicennia marina, to produce cellulase (Maria and Sridhar 2002).

Vibrio is one of the notorious pathogens, and a leading cause of shrimp and fish aquaculture disease. Bacteria from the genus Vibrio have caused enormous losses in the shrimp and fish industry due to mass death and slowing of the growth rate of the fingerlings. The Vibrio also infects people consuming raw or undercooked seafood as a case in Japan where a man has reported to be infected by $V$. vulnificus through fish ( $\mathrm{Li}$ et al. 2018). The objective of this study was to explore the mangrove-associated fungi as sources of protease and cellulase enzymes and/or antiVibrio compounds.

\section{MATERIAL AND METHODS}

\section{Location of sampling sites}

The natural mangroves are naturally formed mangrove ecosystems, while the restoration mangroves are the mangrove forests that humans have replanted. Samples were collected from 9 to 11 April 2019, from two natural and three restoration sites viz. Likupang Restoration (MSr), $1^{\circ} 40$ '33.82"N/125 ${ }^{\circ} 3^{\prime} 17.24 " E$; Likupang Natural (MSn), $1^{\circ} 40^{\prime} 41.76 " \mathrm{~N} / 125^{\circ} 3^{\prime} 14.20^{\prime \prime} \mathrm{E}$; Tiwoho Natural (MT), $1^{\circ} 35^{\prime} 57.01^{\prime \prime N} / 124^{\circ} 51^{\prime} 32.25^{\prime \prime E}$; Bawoho Restoration (MBa), 1'34'51.69"N/12449'3.26"E; Buyat Restoration (MB), $0^{\circ} 50^{\prime} 57.01^{\prime \prime N} / 124^{\circ} 42^{\prime} 27.56^{\prime \prime E ~(F i g u r e ~ 1) . ~ T h e ~}$ collected samples (leaf, branch, root, and sediments) were put into sterile plastic bags to avoid contamination and brought to the laboratory in a cool-box $\left(4^{\circ} \mathrm{C}\right)$ for further treatment.

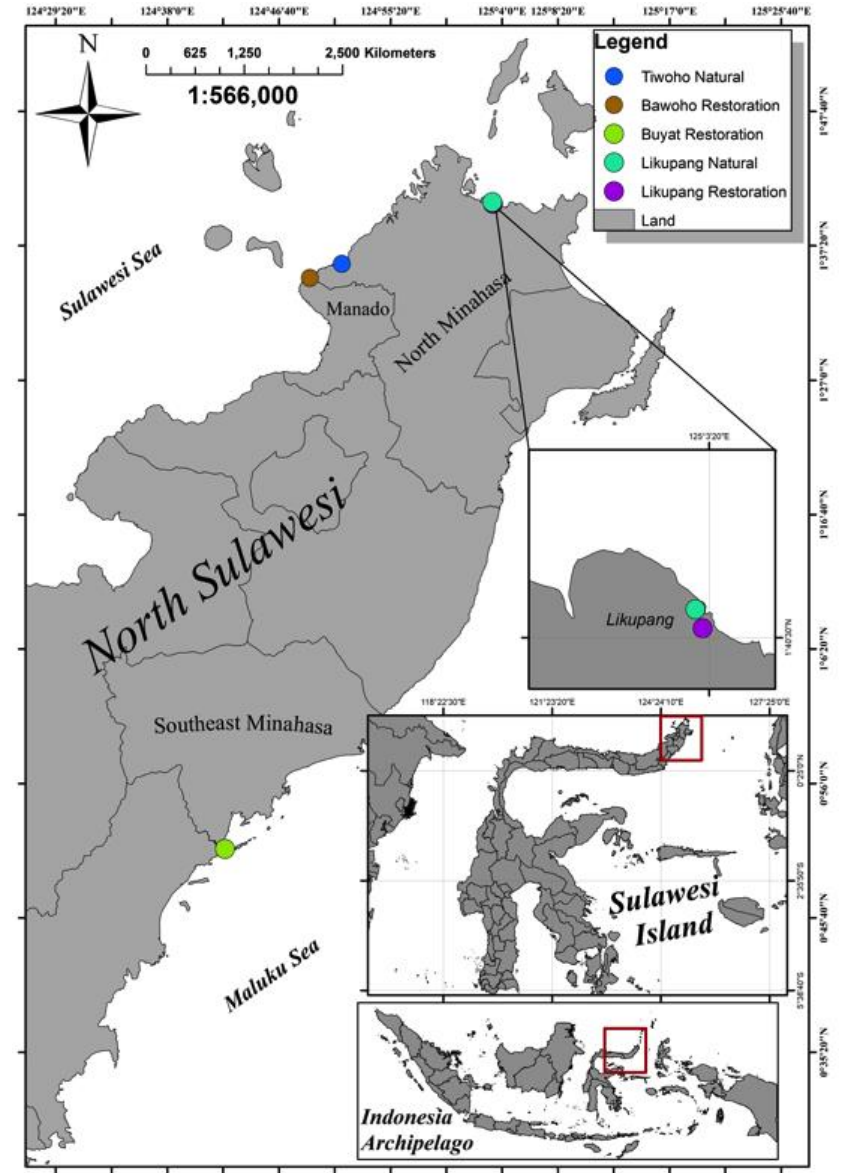

Figure 1. Map of the study areas in the Manado, North Sulawesi, Indonesia. Mangroves showing five sampling sites; Likupang Restoration, MSr (1); Likupang Natural, MSn (2); Tiwoho Natural, MT (3); Bawoho Restoration, MBa (4); and Buyat Restoration, MB (5)

\section{Screening for cellulolytic and proteolytic of fungi}

A total of 288 fungal isolates were tested for their ability to produce cellulolytic and proteolytic enzymes. For Proteolytic screening, the isolates were inoculated on PDA media supplemented with $1 \%$ skimmed milk powder and incubated for 3-5 days at $30{ }^{\circ} \mathrm{C}$. A clear zone around the colony indicated the presence of protease activity (BonugliSantos et al. 2015). Screening of cellulolytic activity was done by inoculating the fungi on the media (containing $1 \%$ peptone, $0.05 \%$ yeast extract, $1 \%$ Carboxymethylcellulose (CMC), and $3 \%$ bacteriological agar) and then incubated for 3-5 days at $30{ }^{\circ} \mathrm{C}$, and transferred into a refrigerator (4 ${ }^{\circ} \mathrm{C}$ ) for overnight. Cellulase activity was detected by the presence of clear zone around the fungal colony after the addition of Congo Red. The clear zone diameter was classified into weak $(<2 \mathrm{~mm})$, medium $(3-4 \mathrm{~mm})$, and strong $(>5 \mathrm{~mm})$ based on the proteolytic and cellulolytic activities of fungi.

\section{Antibacterial assay}

The Vibrio strains were chosen for antibacterial assay, which was conducted using the overlay method as used in the previous study (Trianto et al. 2019). The fungal isolates were inoculated on MEA media in triplicate. After the 
growth of isolates which usually takes 1-7 days depending upon the growth rate, the Vibrio containing soft agar was poured onto the plates. The soft agar was composed of $(0.3 \%(\mathrm{w} / \mathrm{v})$, nutrient broth, $1 \%(\mathrm{w} / \mathrm{v}) \mathrm{NaCl}$ and $0.7 \%(\mathrm{w} / \mathrm{v})$ agar), containing one of the indicator strains with concentration of $0.5 \mathrm{McF}$ arland. The following strains were used for antibacterial testing: Vibrio harveyi, V. vulnificus, and $V$. parahaemolyticus. The plates were incubated at the optimum temperature for bacterial growth $\left(37 \pm 2{ }^{\circ} \mathrm{C}\right)$ for $24 \mathrm{~h}$. The anti-Vibrio activity was defined by the presence of clear zones around the bacterial isolates. The clear zone diameter formed was also used to classify the antibacterial activity of fungi into weak $(<2 \mathrm{~mm})$, medium $(3-4 \mathrm{~mm})$, and strong $(>5 \mathrm{~mm})$.

\section{Molecular identification of the active fungi}

The DNA of active isolates was extracted using the Zymo DNA kit. The universal primer, internal transcribed spacer (ITS) was used for the fingerprint region for fungal barcoding using polymerase chain reaction (PCR) thermal cycler. The PCR mix contained GoTaq ${ }^{\circledR}$ Green Master Mix $12.5 \mu 1$, ITS 1 primer $0.25-2.5 \mu 1$, ITS 4 primer 0.25 $2.5 \mu 1$, DNA template $1-5 \mu 1$, Nuclease-Free Water to total $25 \mu 1$. The thermal cycler setting used was denaturation at $95^{\circ} \mathrm{C}$ for $1 \mathrm{~min}$; 34 cycles of denaturation at $95^{\circ} \mathrm{C}$ for 3 min, annealing at $56.1^{\circ} \mathrm{C}$ for $1 \mathrm{~min}$, extension at $72^{\circ} \mathrm{C}$ for 1 min; last extension at $72^{\circ} \mathrm{C}$ for $7 \mathrm{~min}$ and cooling at $4^{\circ} \mathrm{C}$ until recovery of the samples. The PCR products were visualized by electrophoresis process, and sequencing was undertaken at Genetika Science, Jakarta Indonesia, and continued to 1 st Base, Malaysia. The results were compared with other sequences in the NCBI database using BLAST. The phylogenetic tree of sequence results was constructed by MEGA 7.0 (Kumar et al. 2016).

\section{RESULTS AND DISCUSSION}

\section{Fungal isolates}

A total of 288 fungal isolates were collected from 5 different locations (Figure 1) having vegetation of four genera of mangrove, viz. Sonneratia sp., Rhizophora sp., Avicennia sp., and Lumnitzera sp. Figure 2 showed the mangrove vegetation in North Sulawesi.

\section{Isolation of mangrove-associated fungi}

The total number of samples collected was 84 from 5 sites (Figure 1), which is shown in Figure 3. The highest number of samples was collected from Tiwoho Natural with 29 samples, followed by Likupang Restoration and Buyat Restoration locations, from which 17 and 16 samples were collected, respectively. Tiwoho Natural area was the most interesting location with respect to the diversity of mangrove samples obtained. This area is part of Bunaken National Park that is a protected mangrove area. The total number of fungi that were successfully isolated was 288 isolates. The highest amount of fungi was 96 isolates from Tiwoho Natural. The ratio from 5 locations (MSr, MSn, MT, MBa, MB) showed that the ratio of fungal association to the number of the sample was to be around 2.6 to 3.7. Interestingly, the highest ratio of 3.7 was observed in Buyat Restoration.

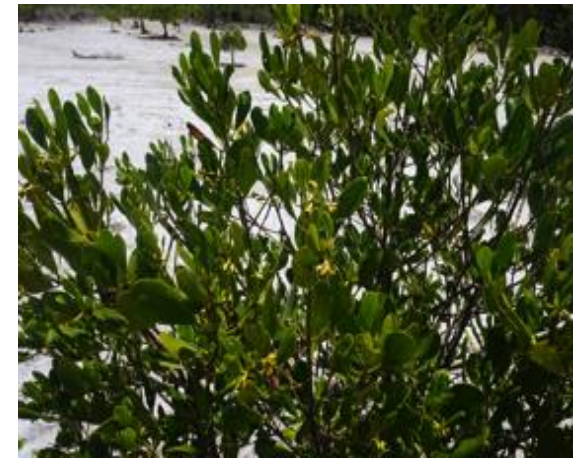

A

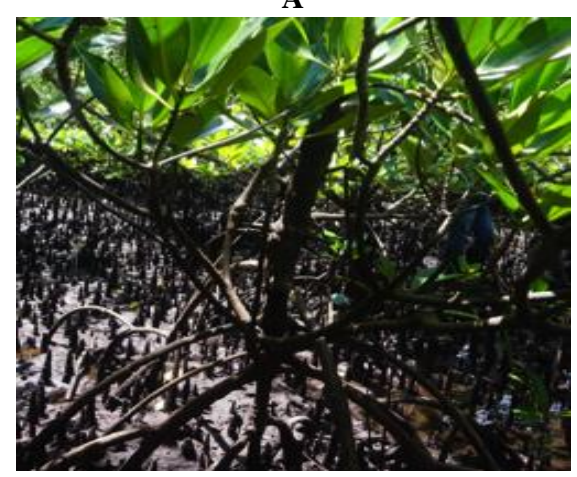

D

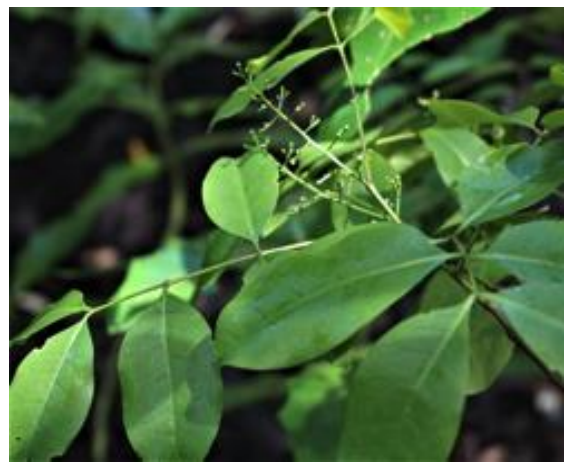

$\mathbf{B}$

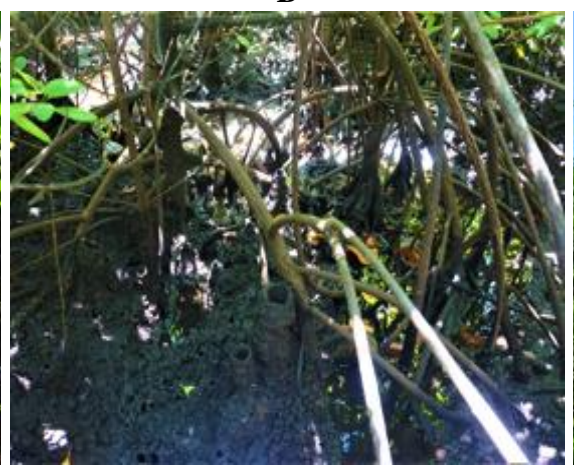

$\mathbf{E}$

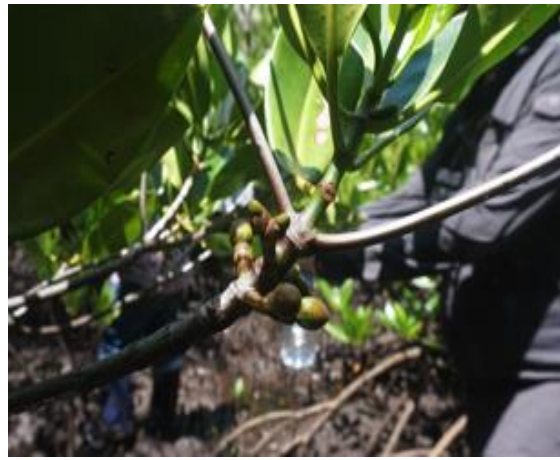

C

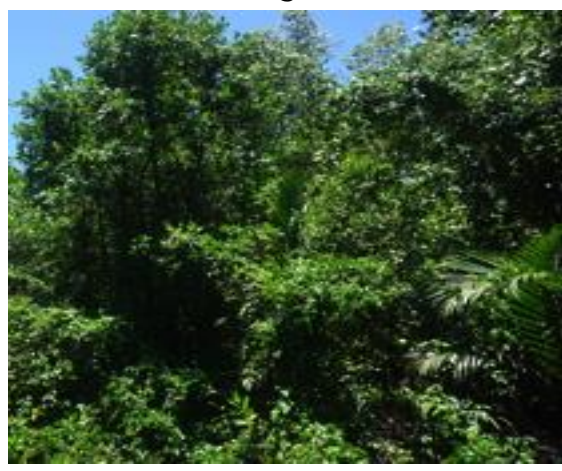

$\mathbf{F}$

Figure 2. Samples of the study areas in Manado, North Sulawesi, Indonesia. A. Sonneratia sp., B. Rhizophora sp., C. Lumnitzera sp., D. Root and sediment of Avicennia sp., E. Litters, F. Mangrove forest 


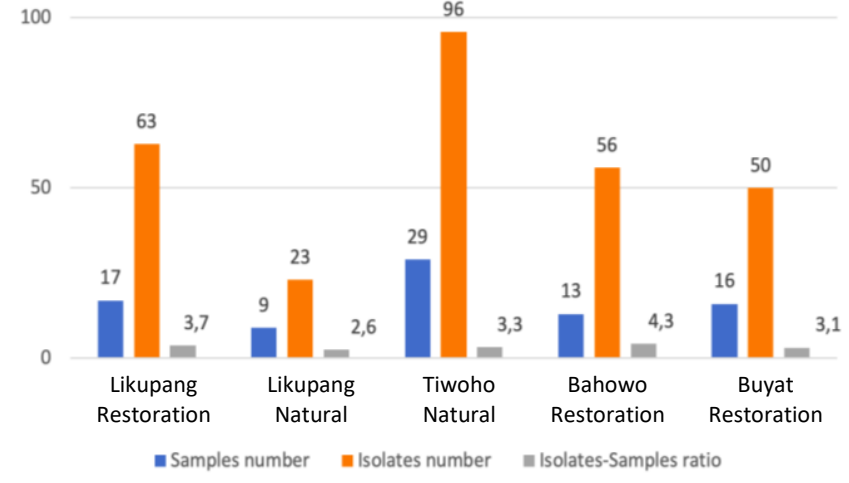

Figure 3. The number of samples and corresponding isolates collected from several locations in North-Sulawesi and their isolate-sample ratio

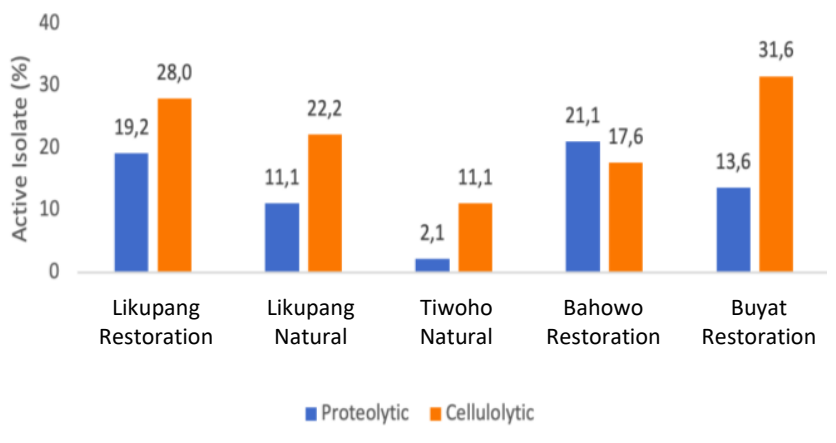

Figure 4. The fungal isolate (\%) having cellulolytic and proteolytic activities

\section{The cellulolytic and proteolytic activities}

It was observed that the fungal isolates had cellulolytic and proteolytic activities, as shown in Figure 4. The percentage of the proteolytic enzyme was $2.1 \%$ to $21.1 \%$. Moreover, the range of cellulolytic enzyme was identified at $11.1 \%$ to $31.6 \%$. Each location had distinct potential activity in terms of enzyme production. The location in Bahowo restored and Buyat Restoration had higher production of the enzyme with proteolytic and cellulolytic activities respectively, than other places. Tiwoho Natural ranked lowest in terms of enzyme production. Two other locations, Likupang Natural and Bahowo Restored had a similar result of proteolytic enzyme in range 11.1 to $21.1 \%$ and cellulolytic enzyme in range 17.6 to $22.2 \%$.

The fungi isolated from leaves were found to be the most potent sources of the enzymes, where $33.3 \%$ of them produced protease and cellulase (Figure 5). Followed by roots, whose isolates produced $25 \%$ cellulases and $20 \%$ of proteolytic enzyme. Branches produced $5.6 \%$ of cellulases and $11.1 \%$ of proteolytic enzyme, moreover, sediment isolates produced $26.7 \%$ of cellulases and $6.7 \%$ of proteolytic enzyme, while, isolates from litters did not have any proteolytic activity.

\section{Antibacterial assay}

The result of antimicrobial activity of mangrove-fungi associated with $V$. harveyi, $V$. vulnificus, and $V$. parahaemolyticus was shown in Figure 6 and Figure 7. Based on the collection sites, most of them had antimicrobial activity with varying potential. The highest anti-Vibrio activity (47.6\%) was represented by fungal isolate from Bawoho Restoration which had antimicrobial activity against $V$. harveyi, While, fungal isolates from Likupang Natural had the highest antimicrobial activity (20\%) against $V$. vulnificus. A total $45.1 \%$ of fungal isolate from Tiwoho Natural had highest antimicrobial activity against $V$. parahaemolyticus. Then, based on the fungal association of the part of mangrove (Figure 7), it was known that most of them had strong antimicrobial activity against $V$. harveyi, $V$. vulnificus, and $V$. parahaemolyticus. There is no antimicrobial activity against $V$. vulnificus, and $V$. parahaemolyticus as observed on the fungal isolates from Litters. The strongest activity was investigated on fungi from sediment against $V$. harveyi at $45.5 \%$.

Table 1. Isolate source, BLAST identified potential species and biological activity of fungi associated mangrove as proteolytic, cellulolytic and anti-Vibrio

\begin{tabular}{|c|c|c|c|c|c|c|}
\hline \multirow{2}{*}{ Isolate code } & \multirow{2}{*}{$\begin{array}{c}\text { Source of mangrove } \\
\text { part }\end{array}$} & \multicolumn{3}{|c|}{$\begin{array}{c}\text { Biological activity } \\
\end{array}$} & \multirow{2}{*}{ Identified species } & \multirow{2}{*}{ ACC number } \\
\hline & & Proteolytic & Cellulolytic & Anti-Vibrio & & \\
\hline 19 Mba-C2-4 & Leaf of Avicennia sp. & + & & & Pestalotiopsis theae & AY924274.1 \\
\hline 19 Mba-C2-1 & Leaf of Avicennia sp. & + & & & Fusarium equiseti & KT459349.1 \\
\hline 19 Mba-C1-1 & Branch of Avicennia sp. & & & + & Penicillium citrinum & KT844552.1 \\
\hline 19 MSr-B3-4 & Root of Sonneratia sp. & + & + & & Fusarium equiseti & MF471699.1 \\
\hline $19 \mathrm{MSr}-\mathrm{B} 3-5$ & Root of Sonneratia sp. & + & & & Pestalotiopsis microspora & KT459349.1 \\
\hline 19 MB-B7-4 & Litters Rhizophora sp. & & + & & Nigrospora sphaerica & KC505176.1 \\
\hline 19 MSr-B2-3 & Leaf of Sonneratia sp. & & + & & Hypocrea jecorina & MN310399.1 \\
\hline 19 MT-10-2 & Leaf of Rhizophora sp. & & + & & Aspergillus aculeatus & MH892845.1 \\
\hline 19 MT-04-3 & Root of Rhizophora sp. & & & + & Trichoderma viride & MK841023.1 \\
\hline $19 \mathrm{MSr}-\mathrm{C} 4-3$ & Sediment & & + & & Diaporthe stewartii & KU204517.1 \\
\hline 19 МТ-05-3 & Sediment & & + & & Hypocrea sp. & MG711900.1 \\
\hline
\end{tabular}




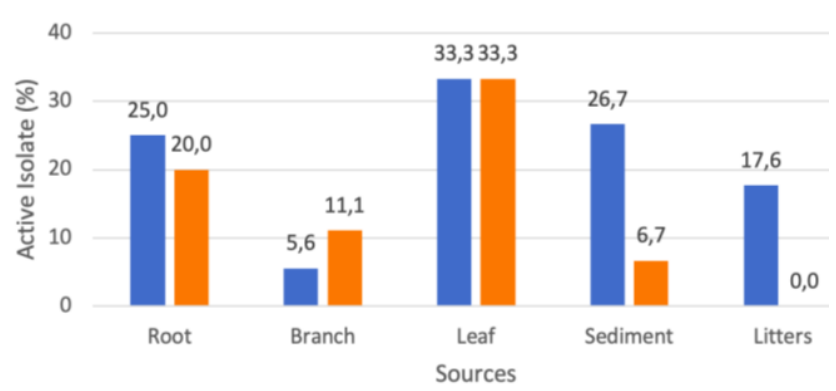

- Cellulolityc Activity = Proteolityc Avtivity

Figure 5. The fungal isolate (\%) from various samples having cellulolytic and proteolytic activities

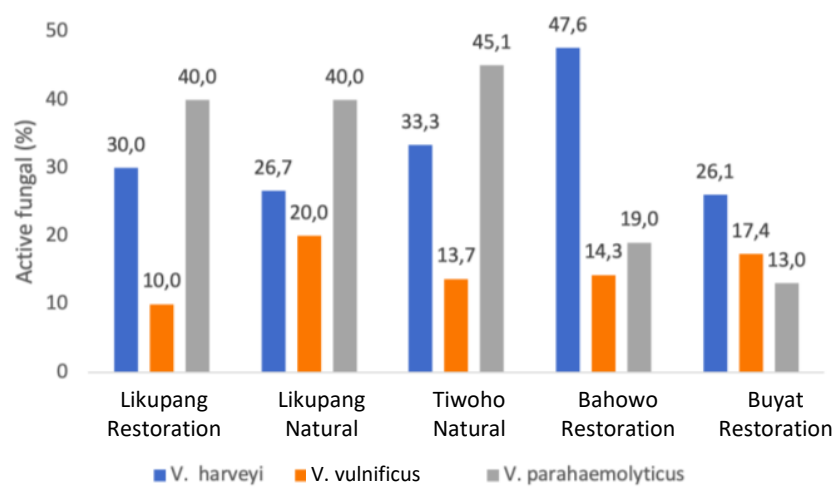

Figure 6. Site wise fungal isolate (\%) active against Vibrio harveyi, V. vulnificus, and V. parahaemolyticus (\%)

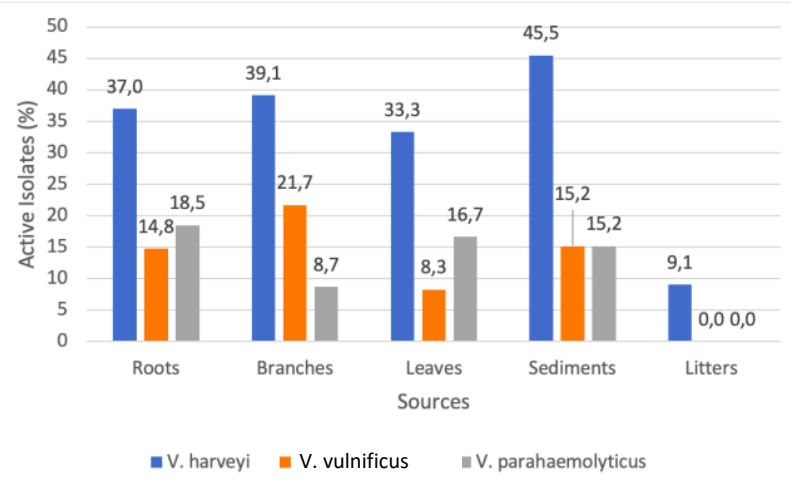

Figure 7. Source-wise fungal isolate (\%) active against Vibrio harveyi, V. vulnificus, and V. parahaemolyticus

\section{Molecular identification of fungal isolates}

Phylogenetic trees were build using maximum likelihood method with bootstrap replicates of 1000 in MEGA 7.0.26 bioinformatics software. The tree represents phylogenetic diversity between restoration area and natural area. The accession number of each species was written in bold and italic style right after the species name. the scale bar at the bottom of the figure represents the distance of evolutionary sequence.

\section{Biological activity of isolated fungi}

The proteolytic and cellulolytic activity as well as antiVibrio activity of the fungal isolates, their BLAST identified potential species, source of mangrove parts are shown in Table 1. Pestalotiopsis theae and Fusarium equiseti isolated from leaf of Avicennia sp., Fusarium equiseti, Pestalotiopsis microspora PKT2, and Fusarium equiseti isolated from root of Sonneratia sp. were the five fungi which had proteolytic activities. The genus Pestalotiopsis causes leaf spots, petiole/rachis blights, and sometimes a bud rot of palms. In other words, unlike the other leaf spot and petiole blight pathogens, which attack either the leaf blade or the leaf petiole, Pestalotiopsis attacks all parts of the leaf from base to tip (Elliott 2018). Fusarium equiseti is commonly found in tropical and subtropical areas, and is considered to be a weak pathogen on cereals and is occasionally to be associated with fusarium head blight infected kernels. Isolation of Fusarium species in greater number and frequency may be due to the high nutrient level in the mangrove ecosystem (Selvi and Sivakumar 2013).

\section{Discussion}

Mangrove ecosystems are a relatively unexplored source of fungal diversity and these fungi represent a potential important commercial reservoir of novel enzymes and compounds with novel activities e.g. new antibiotics, larvacides, etc. (Thatoi et al. 2013; Pringgenies et al. 2018; Sibero et al. 2018). Bonugli-Santos et al. 2015 reported that mangrove associated fungi are endowed with rich sources of enzymes with biotechnological application, such as hydrolytic and/or oxidative enzymes, with alginate lyase, amylase, cellulase, chitinase, glucosidase, inulinase, keratinase, ligninase, lipase, nuclease, phytase, protease, and xylanase.

This work focused on isolating fungi from natural and restored mangrove systems in Northern Sulawesi and it was thought that the different sites could harbor different species due to variation in mangrove species, tidal systems, and restoration methods used. A total of 288 species with the highest diversity found in Tiwoho Natural. Fungi in classesSordariomycetes and Eurotiomycetes were among the most prevalent in mangrove environments which is in agreement with previous studies (Lee et al. 2019). Previous study has reported the diversity of fungi associated with different parts such as fruits, leaves, pneumatophores, and sediments. They reported that fruit and leaf is the highest amount. On average, our study showed that fungi isolate produced protease and cellulose enzymes. The fungal association from leaf showed the highest production of proteolytic and cellulolytic enzymes (Figure 5). Mangrove fungal cellulolytic activity is reported to be affected by environmental conditions ( $\mathrm{pH}$, temperature, substrates), fungal community, and culture conditions (Hossain 2016). Fungi that have proteolytic activity have the ability to produce protease enzymes that are secreted into their environment. The proteolytic enzyme works to hydrolyze protein compounds into oligopeptides, short-chain peptides and amino acids. This extracellular protease enzyme is very important for bacterial life because it provides nitrogen 
compounds that can be transported into cells. The types of fungi that can secrete protease have great potential to be used as a source of aquaculture probiotics, especially in shrimp farming (Setyati et al. 2016).

Our study showed Likupang has complex aquatic dynamics. Likupang-restored mangrove area had abandoned shrimp pond with water rich in protein and cellulose from the waste of shrimp and unconsumed feed. The abundance of pollutant sources from the ponds provides a source of nutrients needed by microbes, therefore Likupang-restored had a high number of isolates and isolate-sample ratio (Saiya and Katoppo 2015; Ruete et al. 2016). Moreover to the contrary, it was surprising that in Likupang-Natural has the lowest ratio of isolates to samples. Sridhar and Seetharam (2001) reported loss of over 300 species of aquatic hyphomycete species due to negative effect of polluted water on fungal diversity. In laboratory experiments, water pollutants that contain low concentrations of $\mathrm{Cd}, \mathrm{Cu}$, and $\mathrm{Zn}$ have been shown to inhibit growth and reproduction of aquatic hyphomycetes and fungi respond by synthesizing specific stress peptides (Krauss et al. 2011).

Mangrove leaves were the best source of fungal isolates producing protease and cellulase enzymes (Figure 5). The study of Chi et al. (2019) revealed that fungi associated with leaves of mangrove had a highly diverse fungal community, where a total of 110 taxa were recovered from isolation and metabarcoding methods; among them, Ascomycota was dominant, which includes Corynespora cassiicola (6.90\%), F. oxysporum $(6.40 \%)$ and Guignardia sp. $(6.40 \%)$. Only specifically fungal isolates sourced from sediments reported anti-Vibrio activity. The fungi that live in seawater sediment are reported to grow well than in freshwater. Sediment nutrient content is affected by physiology and environment among the mangrove vegetation. Previous studies have reported that fungi from different locations, bottom sediment and depth, identified Phycomycetes, Ascomycetes, and Deuteromycetes (Sivakumar 2013).

Fungi use mechanisms like extracellular precipitation, valence transformation and active uptake (e.g. bio-sorption to cell wall and pigments, intracellular compartmentation, complexation and crystallization, and sequestration) and therefore could be used to degrade, accumulate or remove metal pollutants. Thus, screening of metal tolerant fungi has the potential of providing strains with improved metal accumulation. However, the search for microorganisms capable of metal bio- sorption and sequestration has mainly focused on contaminated sites (Ojuederie and Babalola 2017; Igiri et al. 2018).

An interesting fungi Hypocrea jecorina have been found in litters of Rhizophora sp. with cellulolytic enzymatic activity. Hypocrea jecorina (anamorphic Trichoderma reesei) is a saprophyte noted for its ability to abundantly secrete native hydrolytic enzymes. These enzymes are used in various industrial applications, such as pulp and paper production, and the food and feed industries, and the textile industry (Steiger et al. 2011). Penicillium citrinum and Trichoderma viride have been successfully isolated from branch of Avicennia sp. and root of Rhizophora sp., respectively.

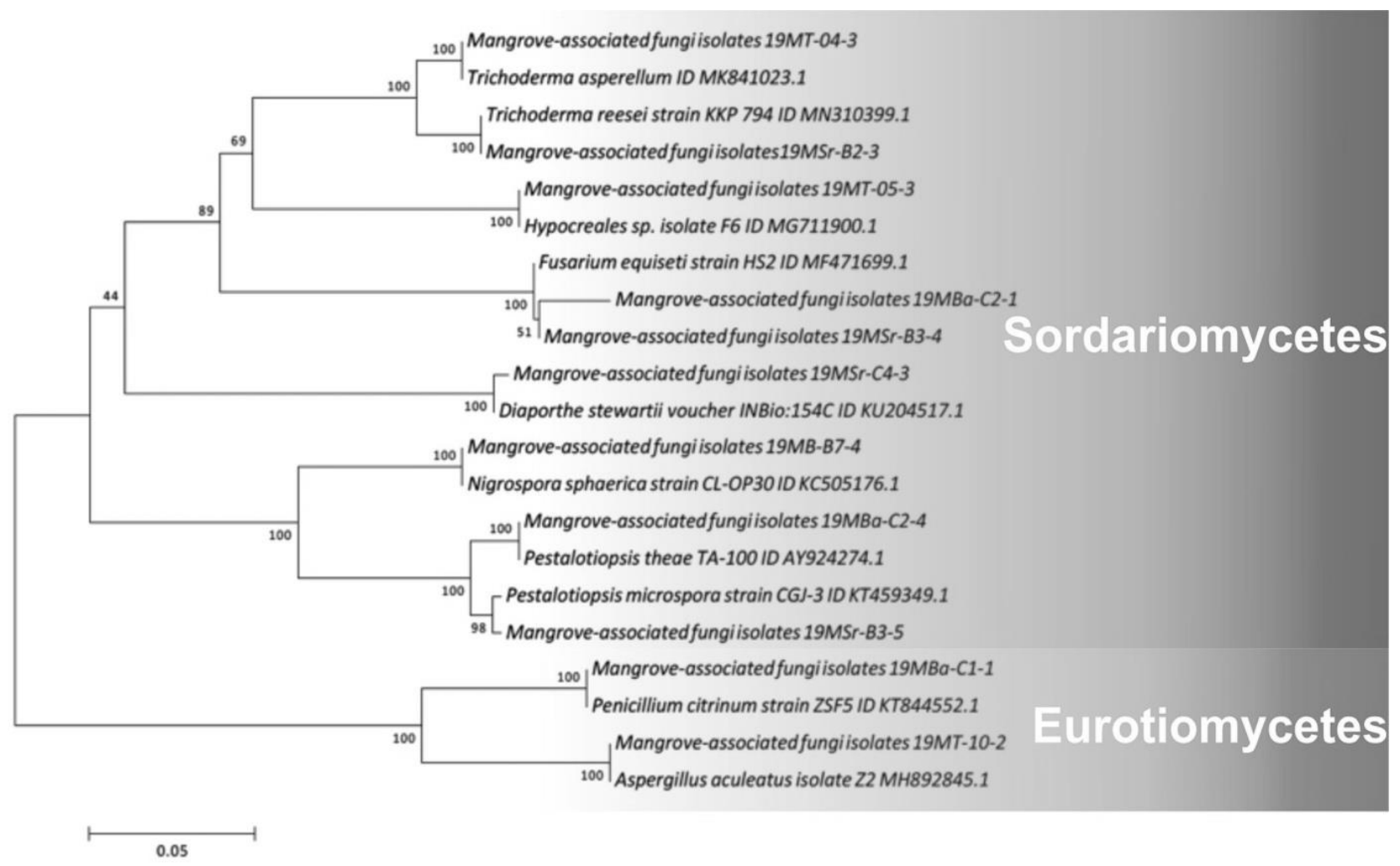

Figure 8. Phylogenetic trees constructed with sequence of active isolates along with BLAST derived sequences 
We showed anti-Vibrio activity of Penicillium citrinum and Trichoderma viride. Previous study has shown four new compounds, penicitrinone $\mathrm{E}$, penicitrinol $\mathrm{J}$, penicitrinol $\mathrm{K}$, and citrinolactone $\mathrm{D}$, that were isolated together with six known compounds from the marinederived Penicillium sp. ML226 (Wang et al. 2013). While, penicitrinone $\mathrm{E}$, penicitrinol $\mathrm{J}$ and penicitrinol $\mathrm{K}$ showed modest selective cytotoxicity against HepG-2 cell line, citrinolactone D showed weak cytotoxicity against HepG-2 and HeLa cell lines. penicitrinol $\mathrm{J}$ and penicitrinol $\mathrm{K}$ also showed mild antimicrobial activity against Staphylococcus aureus (Wang et al. 2013).

\section{ACKNOWLEDGEMENTS}

This work was supported by grants from the DRPMMinistry of Research Technology and Higher Education, Indonesia through Basic Research Scheme with contract number: No. 201-01/UN7.P4.3/PP/2019. and No. 25715/UN7.P 4.3/PP/2019.

\section{REFERENCES}

Bonugli-Santos RC, dos Santos Vasconcelos MR, Passarini MRZ, Vieira GAL, Lopes VCP, Mainardi PH, dos Santos JA, Duarte L de A, Otero IVR, Yoshida AM da S, Feitosa VA, Pessoa Jr A, Sette LD. 2015. Marine-derived fungi: Diversity of enzymes and biotechnological applications. Front Microbiol 6: 269. DOI: 10.3389/fmicb.2015.00269.

Brown B, Djamaluddin R. 2017. A site history and field guide for ecological mangrove rehabilitation in Tiwoho Village, Bunaken National Marine Park, North Sulawesi, Indonesia. Center Int For Res 1-40. DOI: $10.17528 /$ cifor/006397.

Chi WC, Chen W, He CC, Guo SY, Cha HJ, Tsang LM, et al. 2019. A highly diverse fungal community associated with leaves of the mangrove plant Acanthus ilicifolius var. xiamenensis revealed by isolation and metabarcoding analyses. PeerJ 7: e7293. DOI: 10.7717/peerj.7293.

Djamaluddin R. 2018. The mangrove flora and their physical habitat characteristics in Bunaken National Park, North Sulawesi, Indonesia. Biodiversitas 19 (4): 1303-1312. DOI: 10.13057/biodiv/d190417.

Elliott ML. 2018. Pestalotiopsis (Pestalotia) Diseases of Palm. IFAS Extension, University of Florida, Miami, FL.

Hadika A, Karuniasa M. 2020. Mangrove's vegetation structure and composition (a study: Manado City, North Sulawesi Province). In: Saiya HG et al. (eds) Proc Int Conf Environ Sci Sustain Develop, 2223 October 2019, Jakarta, Indonesia. DOI: 10.4108/eai.22-102019.2291477.

Hossain MM. 2016. On identifying the SARIMA model to forecast the humidity of some selected stations in Bangladesh. Int J Environ Sci 6: 1080-1089. DOI: 10.6088/ijes.6102.

Igbinosa EO, Omoruyi G Idemudia OG. 2016. Anti-vibrio potentials of acetone and aqueous leaf extracts of Ocimum gratissimum (Linn) Trop J Pharm Res 15 (4): 743-750. DOI: 10.4314/tjpr.v15i4.11.

Igiri BE, Okoduwa SIR, Idoko GO, Akabuogu EP, Adeyi AO, Ejiogu IK. 2018. Toxicity and bioremediation of heavy metals contaminated ecosystem from tannery wastewater: A review. J Toxicol 2018: 25680386. DOI: $10.1155 / 2018 / 2568038$.

Immaculatejeyasanta K, Madhanraj P, Patterson J, Panneerselvam A. 2011. Case study on the extracellular enzyme of marine fungi associated with mangrove driftwood of Muthupet Mangrove, Tamil Nadu, India. J Pharmacy Res 4: 1385-1387.

Indarsih R, Masruri MS. 2019. Mangrove conservation as an abrasion strategy risk reduction based on ecosystem in the coastal area of the Rembang Regency. IOP Conf Ser: Earth Environ Sci 271: 012021.
Kamath P, Subrahmanyam VM, Rao JV, Raj PV. 2010. Optimization of cultural conditions for protease production by a fungal species. Indian J Pharm Sci 72 (2): 161-166. DOI: 10.4103/0250-474X.65017.

Kelecom A. 2002. Secondary metabolites from marine microorganisms. An Acad Bras Ciênc 74: 151-170. DOI: 10.1590/s000137652002000100012 .

Krauss F, Bärlocher F, Krauss GJ. 2011. Effects of pollution on aquatic hyphomycetes. In: Tsui CKM, Hyde KD (eds) Freshwater Mycology, Fungal Diversity Press, Hong Kong.

Kumar S, Stecher G, Tamura K. 2016. MEGA7: Molecular evolutionary genetics analysis version 7.0 for bigger datasets. Mol Biol Evol 33 (7): 1870-1874. DOI: 10.1093/molbev/msw054.

Lee NLY, Huang D, Quek ZBR, Lee JN, Wainwright BJ. 2019. Mangrove-associated fungal communities are differentiated by geographic location and host structure. Front Microbiol 10: 2456. DOI: $10.3389 /$ fmicb.2019.02456.

Li L, Wang L, Zhang C, Chen P, Luo X. 2018. A case of Vibrio vulnificus related wound infection diagnosed by next-generation sequencing. IDCases 15: e00497. DOI: 10.1016/j.idcr.2019.e00497.

Sari SLA, Setyaningsih R, Wibowo NFA. 2017. Isolation and screening of cellulolytic fungi from Salacca zalacca leaf litter. Biodiversitas 18 (3): 1282-1288. DOI: 10.13057/biodiv/d180355.

Maitig AMA, Alhoot MAM, Tiwari K. 2018. Isolation and screening of extracellular protease enzyme from fungal isolates of soil. J Pure Appl Microbiol 12 (4): 2059-2067. DOI: 10.22207/JPAM.12.4.42.

Maria GL, Sridhar KR. 2002. Richness and diversity of filamentous fungi on woody litter of mangroves along the west coast of India. Curr Sci 83 (12): 1573-1580.

Nehren U, Ho Dac Thai H, Trung ND, Raedig C, Alfonso S. 2017. Sand dunes and mangroves for disaster risk reduction and climate change adaptation in the coastal zone of Quang Nam Province, Vietnam. In: Nauditt A, Ribbe L (eds) Land Use and Climate Change Interactions in Central Vietnam. Water Resources Development and Management. Springer, Singapore. DOI: 10.1007/978-981-10-2624-9_13.

Ojuederie OB, Babalola OO. 2017. Microbial and plant-assisted bioremediation of heavy metal polluted environments: A review. Int $\mathbf{J}$ Environ Res Public Health 14 (12): 1504. DOI: 10.3390/ijerph14121504.

Pringgenies D, Widiyadmi R, Yudiati E, Bahry MS, Djunaedi A. 2018. Potentials of mangrove fruit extract Xylocarpus granatum for Aedes aegypti mosquito repellent. J Trop Mar Sci 1: 1-6. DOI: 10.33019/jour. trop.mar.sci.v1i1.657. [Indonesian]

Ramesh K, Natarajan M, Sridhar H, Uma Vanitha M, Umamaheswari S. 2014. Anti-vibrio activity of mangrove and mangrove associates on shrimp pathogen, Vibrio harveyi VSH5. Global Veterinaria 12 (2): 270-276, DOI: 10.5829/idosi.gv.2014.12.02.82211

Ruete A, Snäll T, Jönsson M. 2016. Dynamic anthropogenic edge effects on the distribution and diversity of fungi in fragmented old-growth forests. Ecol Appl 26 (5): 1475-1485. DOI: 10.1890/15-1271.

Saiya HG, Katoppo DR. 2015. Waste management of shrimp farms as starting point to develop integrated farming systems (case study: Kuwaru Coast, Bantul, Yogyakarta, Indonesia). J Degrade Min Land Manage 3: 423-432. DOI: 10.15243/jdmlm.2015.031.423.

Selvi KV, Sivakumar T. 2013. Isolation, identification and characterization of Fusarium species from mangrove habitat of Pichavaram, Tamil Nadu, India. Int J Curr Microbiol Appl Sci 2: 3349.

Setyati WA, Habibi AS, Subagiyo, Ridlo A, Nirwani S, Pramesti R. 2016. Skrining dan seleksi bakteri simbion spons penghasil enzim ekstraseluler sebagai agen bioremediasi bahan organik dan biokontrol vibriosis pada budidaya udang. Jurnal Kelautan Tropis 19: 11-20. DOI: 10.14710/jkt.v19i1.595. [Indonesian]

Sibero MT, Herdikiawan D, Radjasa OK, Sabdono A, Trianto A, Triningsih DW. 2018. Antibacterial activity of sponge-associated fungi against Vibriosis agents in shrimp and its toxicity to Litopenaeus vannamei. AACL Bioflux 11: 10-18.

Sivakumar T. 2013. A review on biodiversity of marine and mangrove fungi. Int J Curr Res Aca Rev 1 (1): 26-44.

de Souza PM, de Assis Bittencourt ML, Caprara CC, de Freitas M, de Almeida RPC, Silveira D, Fonseca YM, Filho EXF, Jr Pessoa A, Magalhães PO. 2015. A biotechnology perspective of fungal proteases. Braz J Microbiol 46 (2): 337-346. DOI: 10.1590/S1517838246220140359. 
Sridhar KR, Seetharam RN. 2001. Aquatic hyphomycetes and leaf litter processing in unpolluted and polluted habitats. In: Misra JK, Horn BW (eds) Trichomyces and other fungal groups. Science Publishers, NH, USA..

Steiger MG, Vitikainen M, Uskonen P, Brunner K, Adam G, Pakula T, Penttilä M, Saloheimo M, Mach RL, Mach-Aigner AR. 2011. Transformation system for Hypocrea jecorina (Trichoderma reesei) that favors homologous integration and employs reusable bidirectionally selectable markers. Appl Environ Microbiol 77 (1): 114-121. DOI: 10.1128/AEM.02100-10.

Thatoi H, Behera BC, Mishra RR. 2013. Ecological role and biotechnological potential of mangrove fungi : A review. Mycology 4 (1): 54-71. DOI: 10.1080/21501203.2013.785448.
Trianto A, Sabdono A, Radjasa OK, Pramesti R, Putrajaya NTS, Bahry MS, Triningsih DW, Sulistiowati, Afriyanto R. 2019. Optimization production of antifungal substance from a sponge-associated Trichoderma harzianum cultivated in the tofu dregs and rice bran. Res J Biotechnol 14: 68-73.

Wang ML, Lu CH, Xu QY, Song SY, Hu ZY, Zheng ZH. 2013. Four new citrinin derivatives from a marine-derived Penicillium sp. fungal strain. Molecules 18 (5): 5723-5735. DOI: 10.3390/molecules 18055723 